\title{
Characterization of Kaolin Deposits in Okpella and Environs, Southern Nigeria
}

\author{
Benjamin Odey Omang1, Ebenezer Agayina Kudamnya', Ayodele Olumiyiwa Owolabi², \\ Joseph Odey3 ${ }^{3}$ Emmanuel Ude Aniwetalu4, Thomas Agbor Ako5 \\ ${ }^{1}$ Department of Geology, University of Calabar, Calabar, Nigeria \\ ${ }^{2}$ Department of Mining Engineering, Federal University of Technology, Akure, Nigeria \\ ${ }^{3}$ Department of Pure and Applied Chemistry, University of Calabar, Calabar, Nigeria \\ ${ }^{4}$ Department of Geological Sciences, Nnamdi Azikiwe University, Awka, Nigeria \\ ${ }^{5}$ Department of Geology, Federal University of Technology Minna, Minna, Nigeria \\ Email: benodey@yahoo.co.uk
}

How to cite this paper: Omang, B.O., Kudamnya, E.A., Owolabi, A.O., Odey, J., Aniwetalu, E.U. and Ako, T.A. (2019) Characterization of Kaolin Deposits in Okpella and Environs Southern Nigeria. International Journal of Geosciences, 10, 317-327. https://doi.org/10.4236/ijg.2019.103018

Received: December 20, 2018

Accepted: March 26, 2019

Published: March 29, 2019

Copyright $\odot 2019$ by author(s) and Scientific Research Publishing Inc. This work is licensed under the Creative Commons Attribution International License (CC BY 4.0).

http://creativecommons.org/licenses/by/4.0/

\begin{abstract}
Kaolin is one of the most important industrial minerals whose application is dependent on its structure and chemical composition. This study makes an attempt to explore and determine the origin of kaolin deposits within and around Okpella, as well as to investigate the mineralogical and chemical compositions using the X-ray diffraction (XRD) and X-ray fluorescence (XRF) method. These were carried out with the intention of determining the most suitable applications for the clay mineral. It was observed that major phases in the clay samples from the three different deposits are kaolinite, microcline, illite/mica, plagioclase/albite and quartz. These phases were observed in varied percentages. Samples from Ajego 2 show a marked absence of kaolinite but contain high concentration of plagioclase feldspar and quartz which permit its usage in the production of glass and iron industries. Further, the samples from Ajego 1 contain by far the highest concentration of kaolinite, while the samples from Anegha consist of kaolinite, a mixed layer of illite/mica, plagioclase, alkali feldspars, and albite which is necessary for producing mullite fibers in ceramic matrix at a temperature of around $1400^{\circ} \mathrm{C}$ and it is suitable in pigment production. The XRF result for Ajego2 and Anegha samples has Silica composition of $51.847 \mathrm{wt} \%, 32.540 \mathrm{wt} \%$ and $37.295 \mathrm{wt} \%$ respectively and an alumina content of $14.962 \mathrm{wt} \%, 29.834 \mathrm{wt} \%$ and $20.227 \mathrm{wt} \%$ respectively. The trace amount of some of the oxides such as $\mathrm{K}_{2} \mathrm{O}, \mathrm{TiO}_{2}, \mathrm{Fe}_{2} \mathrm{O}_{3}$ and $\mathrm{SnO}_{2}$ can help in the beneficiation process.
\end{abstract}

\section{Keywords}

Kaolin, Mineral, Characterization, XRD, XRF, Okpella 


\section{Introduction}

Clay is an abundant fine textured earthly powder produced by the weathering and disintegration of granite and feldspathic rocks [1]. It is richly found in soil, sedimentary rocks and hydrothermal deposits. One fundamental reason for the various applications of certain clay minerals is that the physical and chemical properties of clay minerals are dependent on its structure and composition. For example, the structure and composition of kaolin, smectite, and palygorskite and sepiolite are very different even though they each have octahedral and tetrahedral sheets as their basic building blocks. However, the arrangement and composition of these octahedral and tetrahedral sheets account for major and minor differences in the physical and chemical properties of kaolin, smectites and palygorskite [2]. They possess certain properties that define their wide application for use, and this includes: plasticity, resistance to high temperature, malleability (can be shaped to any form), and complex composite formulations (adding substances to clay with a view to improving the properties and usefulness). Clays may be expandable and Non-expandable clay [3]. Expandable clay swells up when water is added to it, while non-expandable clay does not.

At a moment in time such as now when the Nigerian government attempts to diversify its economy, the exploration of Kaolin deposit in Okpella and environs was undertaken. A proper understanding of the geochemical character of Kaolin in Okpella and environs has remained elusive over the years, thus the need for this study. Kaolin is a white, soft, plastic clay composed mainly of kaolinite, $\mathrm{Al}_{4}(\mathrm{OH})_{8}\left[\mathrm{Si}_{4} \mathrm{O}_{10}\right]$, and other related clay minerals such as nacrite and dickite [4]. Kaolin deposits are classified as primary or secondary according to their genesis; primary deposits originating in situ by alteration, whereas secondary deposits are of sedimentary origin [5]. Primary deposits are formed directly from hydrothermal alteration of volcanic and granitic rocks with examples as hydrothermal and volcanic clay types. Secondary clay deposits are products of weathering of pre-existing rocks, and subsequent alteration of the alumino-silicates into clays such as residual and sedimentary clays. However, clay can further be classified on the basis of genetic and industrial characteristics.

The formation and localization of sedimentary clay are controlled by the location of the sedimentary basin and the presence of weathered feldspar-rich rocks such as granite, syenite or gneiss adjacent to the basin, particularly rapidly eroding paleo-topographic highs. Ideal conditions necessary to produce kaolinitic clays by means of chemical weathering are high rainfall, warm temperatures, lush vegetation, low relief and high groundwater table [6]. Thus, kaolin is eroded and transported by streams to a quiet, fresh or brackish water environment. Post depositional leaching, oxidation, and diagenesis can significantly modify the original clay mineralogy with improvement of kaolin quality [7]. Kaolin has a wide range of application among which is the ceramic industry. Each specific use, to which kaolin is put, requires that it possess certain specific properties. Kaolin is an important raw material with widespread industrial applications 
such as water treatment, as porcelain, cement and ceramics production [8] and equally as fillers for polymer, pigment in paint/inks and plastics/rubber [9] [10]. Some Pigments from kaolin offer opacity and brightness because they have the ability to scatter light. The degree to which the minerals scatter light depends on their intrinsic index of refraction and also on the structure they form in the coating. Titanium dioxide has high refractive index, strong absorption in the UV region of light spectrum and strong reflectance in the visible spectrum thereby giving it a very high light scattering properties which, when combined with its particle size creates an effective pigment for brightness and opacity [11]. Also, some organic pigment form from kaolin absorbs UV light thereby preventing it from damaging the binder in paint formation [12]. The aim of this study therefore is to characterize kaolin deposits within Okpella and its environs using the mineralogical and geochemical constituents of the major oxides present with a view to determining its applicability for industrial purposes.

\section{Description and Geology of the Study Area}

The study area is part of the western Nigerian schist belt (Figure 1). It is located within Latitude $\mathrm{N} 07^{\circ} 09^{\prime}$ to $\mathrm{N} 07^{\circ} 27^{\prime}$ and Longitude $\mathrm{E} 06^{\circ} 24^{\prime}$ to E06 $64^{\prime}$. The study area is situated within the warm-humid tropical climate, which is characterized by a distinctive wet and dry season. The vegetation cover is of the Guinea Savannah type consisting of secondary vegetation in the form of scattered trees, shrubs and grass savannah. Generally, the vegetation has been tempered by human activities mainly for agricultural purposes.

Regionally, the study area is part of the Pre-Cambrian Basement Complex of the south-western Nigeria. [13] identified five (5) major lithological units in the regional setting, they consist of the migmatite-Gniess Complex; slightly migmatised to unmigmatised para-schists and meta-igneous rocks consisting of pellitic

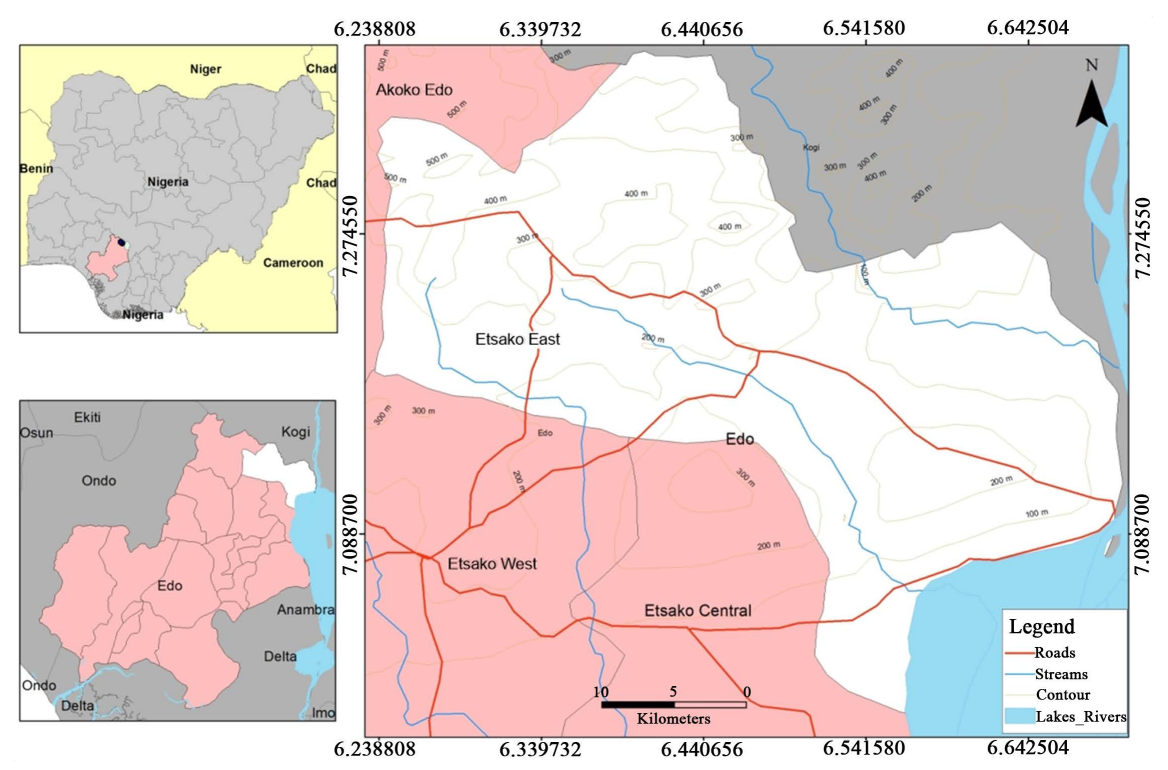

Figure 1. Location map of the study area. 
schist, quartzite, amphibolites, talcose rocks, meta-conglomerates, marbles, calc-silicate rocks; charnokitic rocks; the Older Granites suites comprising of rocks with granodiorite to true granite and potassium syenite; and unmetamorphosed dolerite dykes.

\section{Materials and Method}

A total of ten (10) samples were taken from three (3) different locations mostly from quarry pits where the kaolin is being mined within the study area (Figure 2). The raw kaolin samples were selected to be representative of the different petrographic varieties. This was made possible from field investigation where differences are based on colour and grain sizes.

Sample preparations involve the crushing of each of the non-homogeneous kaolin sample, to fine homogeneous sizes and were then pelletized. The SKYRAY-.EDX3600B X-ray fluorescence spectrometer equipment which applies XRF technology to conduct fast and accurate analysis of complex composition was used. The system detect elements between Sodium $(\mathrm{Na}, \mathrm{Z}=11)$ and Uranium $(U, Z=92)$ with high resolution and fast analysis and subsequently presented in MS-EXCEL spreadsheet format. Also, portions of the pulverized homogeneous kaolin sample were loaded into the XRD sample holder. For this analysis, the equipment GBC eMMA XRD-equipped with a GBC enhanced mini-material analyzer was used. It employs the XRD technology to conduct material analysis using standard XRD reference data. The voltage and current were set to get appropriate power for X-ray source and the powdered samples were then analyzed, and sample relative to peak formation with standard XRD data reference was then presented as diffractographs.

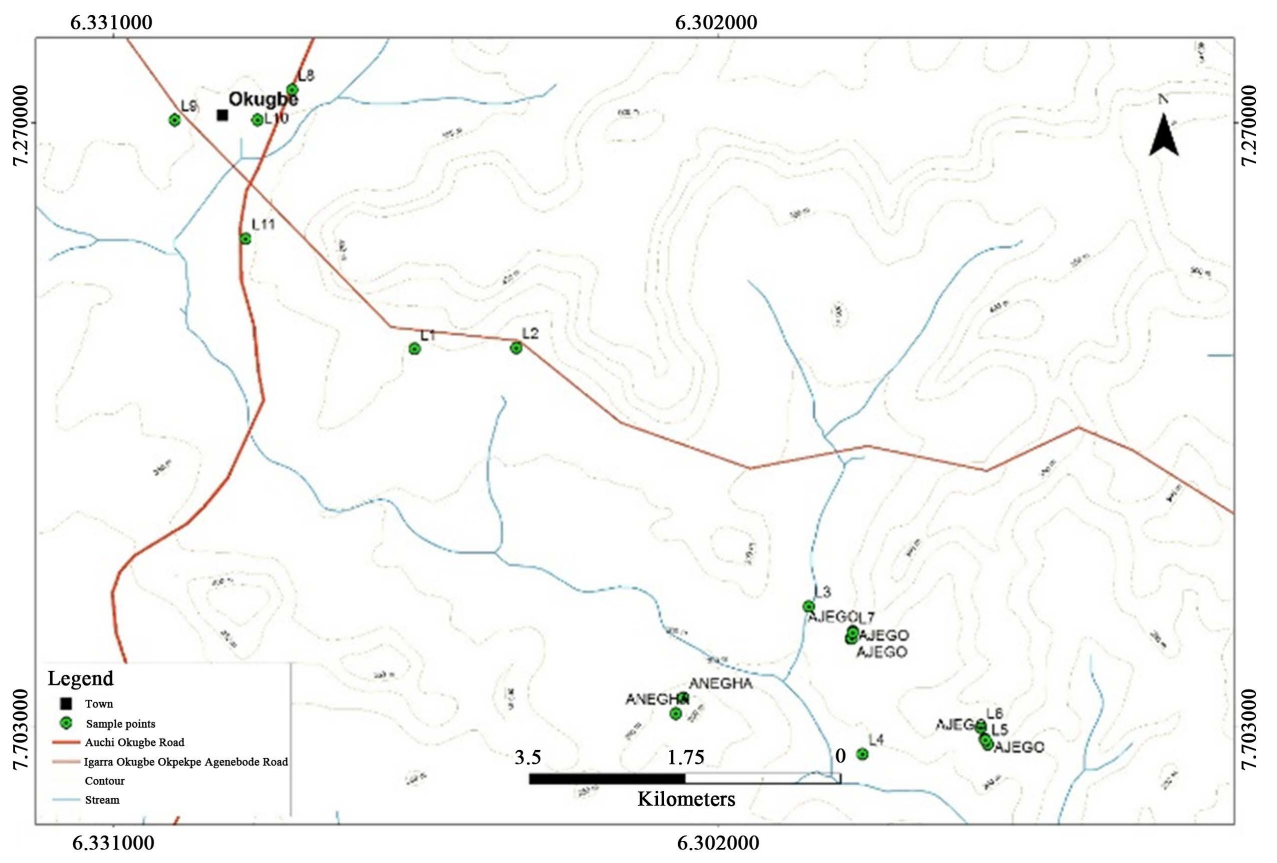

Figure 2. Sample location points within Okpella and its environs. 


\section{Results and Discussion}

From field characteristics of kaolin deposits from Ajego 1 area. The colour ranges from greyish dark to white (Table 1). The textures ranges from smooth to coarse grain, typically with silica composition (Figure 3(b)) while the deposit at Ajego 2 area are predominantly feldspars (Figure 3(a)). They appear pinkish with purple colorations and exhibit a generally smooth texture. The deposit at Dansa quarry situated in Anegha is mostly white (Figure 3(c)) but sometimes greyish and are found to co-exist with coal seams of varying thicknesses.
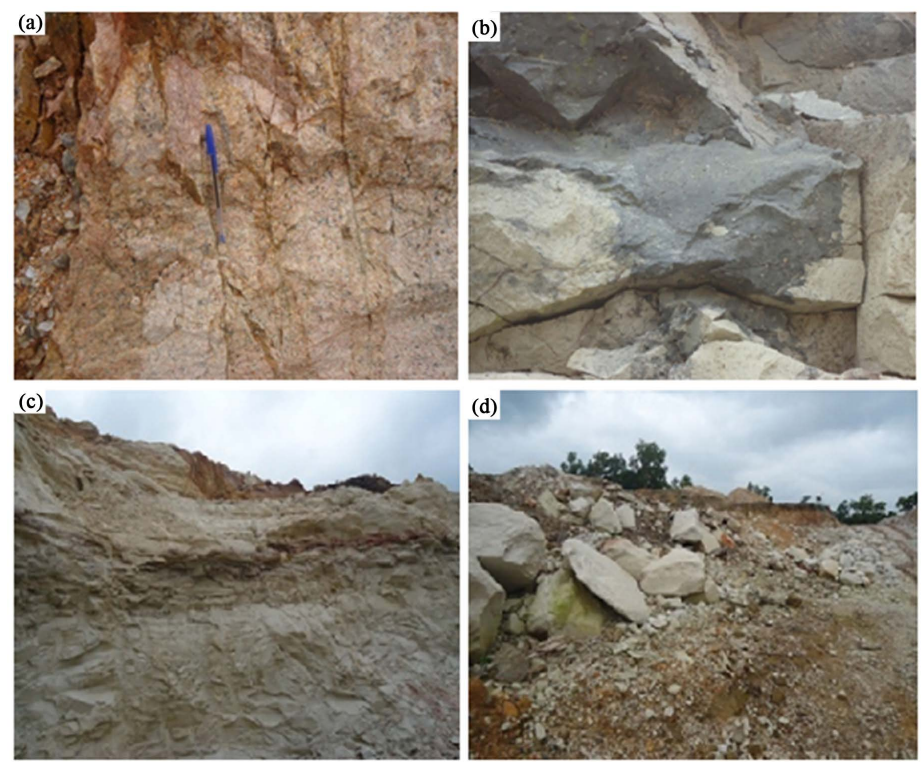

Figure 3. (a) Felspars outcropping at Ajego 2; (b) Grey and white Kaolin outcrop at Ajego 1; (c) and (d) White to brown Kaolin outcrop at Anegha with thick lateritic cover.

Table 1. Field descriptions of kaolin deposits in study area.

\begin{tabular}{|c|c|c|c|c|c|}
\hline S/N. & $\begin{array}{l}\text { Sample } \\
\text { Code }\end{array}$ & Colour & Description & Location & $\begin{array}{l}\text { Rock } \\
\text { type }\end{array}$ \\
\hline 1 & L1S1 & Grey & $\begin{array}{l}\text { Coarse texture with silica matrix } \\
\text { and bands of plant remains }\end{array}$ & Ajego 1 & Kaolin \\
\hline 2 & L1S2 & White & Smooth chalky texture & Ajego 1 & Kaolin \\
\hline 3 & L1S3 & Brownish-white & Coarse texture with matrix of silica & Ajego 1 & Kaolin \\
\hline 4 & L1S4 & Grey & Smooth texture & Ajego 1 & \\
\hline 5 & L2S1 & Pinkish-white & Smooth & Ajego 2 & Feldspar \\
\hline 6 & L2S2 & $\begin{array}{l}\text { White with } \\
\text { purple impurities }\end{array}$ & Smooth & Ajego 2 & Quartz \\
\hline 7 & L2S3 & White & Smooth & Ajego 2 & Quartz \\
\hline 8 & L3S1 & White-brown & Smooth chalky texture & Anegha & \\
\hline 9 & L3S2 & Grey & $\begin{array}{l}\text { Coarse with blank } \\
\text { coal-like impregnation }\end{array}$ & Anegha & Kaolin \\
\hline 10 & L3S3 & White-brown & Smooth texture & & Lignite \\
\hline
\end{tabular}


The results of the XRF analysis carried-out from Ajego 2 and Anegha samples indicates 10 major oxides (Table 2). Samples from Ajego 2 (L2S1) showed that the major component is silica $\left(\mathrm{SiO}_{2}\right)$ with $51.847 \mathrm{wt} \%$, and alumina $\left(\mathrm{Al}_{2} \mathrm{O}_{3}\right)$ content of $14.962 \mathrm{wt} \%$. There is a significant amount of $\mathrm{K}_{2} \mathrm{O}$ with $10.516 \mathrm{wt} \% \mathrm{com}-$ position indicating that there is an abundance of feldspar which correspond with macroscopic observation from field mapping that revealed the abundance of whitish feldspars in the Ajego 2 samples. This conclusion is further accentuated by the X-ray Diffraction results that presented a plagioclase feldspars along with quartz composition. Chemically, Anegha samples (L3S5 and L3S6) have a comparatively proportionate amount of silica to the alumina (Figure 4). The kaolin sample from L3S5 has silica $\left(\mathrm{SiO}_{2}\right)$ composition of $32.540 \mathrm{wt} \%$ and alumina $\left(\mathrm{Al}_{2} \mathrm{O}_{3}\right)$ of $29.834 \mathrm{wt} \%$, while at $\mathrm{L} 3 \mathrm{~S} 6$ silica $\left(\mathrm{SiO}_{2}\right)$ content is up to $37.295 \mathrm{wt} \%$ and alumina $\left(\mathrm{Al}_{2} \mathrm{O}_{3}\right)$ content measuring $20.227 \mathrm{wt} \%$. The amount of silica and alumina composition present in the samples obtained from Anegha is an indication that the tetrahedra to octahedra layers in the clay structure is approximately in the ratio $1: 1$, and this is typical of kaolin clays.

The XRD results revealed that the Ajego 1 area consists mainly of kaolinite, with a mixed layer of illite/kaolinite and quartz (Microcline) as framework constituents (Figure 5). Samples from the Ajego 2 area consists more of plagioclase and alkali feldspar, with albite and quartz composition (Figure 6). The anegha samples consist of kaolinite, mixed layer of illite/mica and the quartz (Microcline) compositions (Figure 7).

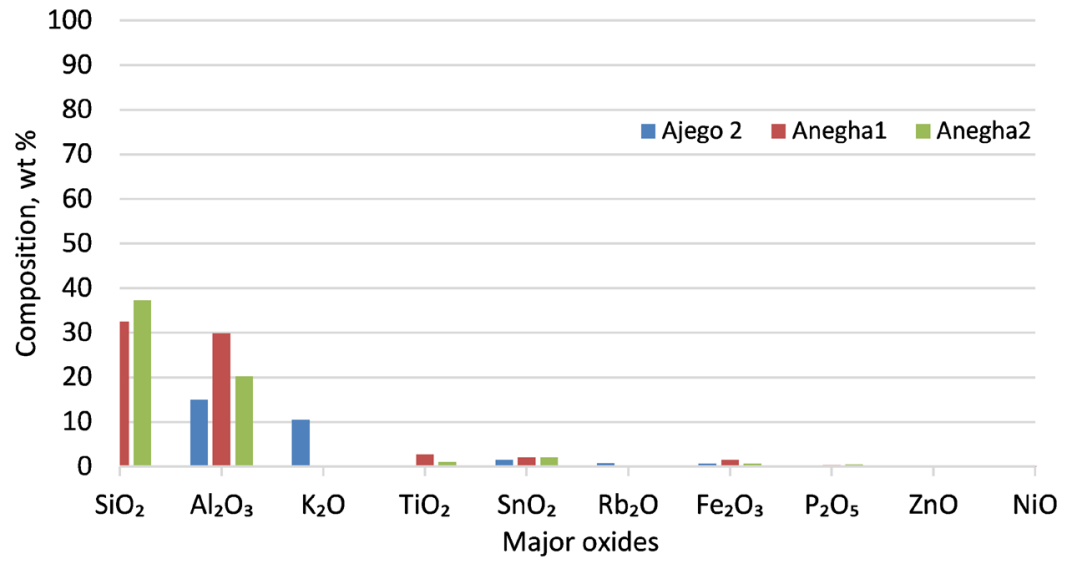

Figure 4. Plot of major oxide composition for Ajego 2 and two locations at Anegha.

Table 2. Chemical composition of some selected samples from Ajego 2 and Anegha using $\mathrm{XRF}$ analysis.

\begin{tabular}{lccccccccccc}
\hline \multirow{2}{*}{ Locality } & $\begin{array}{c}\text { Sample } \\
\text { Code }\end{array}$ & $\mathrm{SiO}_{2}$ & $\mathrm{Al}_{2} \mathrm{O}_{3}$ & $\mathrm{~K}_{2} \mathrm{O}$ & $\mathrm{TiO}_{2}$ & $\mathrm{SnO}_{2}$ & $\mathrm{Rb}_{2} \mathrm{O}$ & $\mathrm{Fe}_{2} \mathrm{O}_{3}$ & $\mathrm{P}_{2} \mathrm{O}_{5}$ & $\mathrm{ZnO}$ & $\mathrm{NiO}$ \\
\hline \multirow{2}{*}{ Ajego 2 } & $\mathrm{L} 2 \mathrm{~S} 1$ & 51.847 & 14.962 & 10.516 & 0.000 & 1.521 & 0.788 & 0.658 & 0.282 & 0.122 & 0.082 \\
& $\mathrm{~L} 3 \mathrm{~S} 5$ & 32.540 & 29.834 & 0.000 & 2.772 & 2.007 & 0.000 & 1.466 & 0.309 & 0.178 & 0.117 \\
Anegha & $\mathrm{L} 3 S 6$ & 37.295 & 20.227 & 0.000 & 1.029 & 2.000 & 0.000 & 0.740 & 0.544 & 0.165 & 0.116 \\
\hline
\end{tabular}




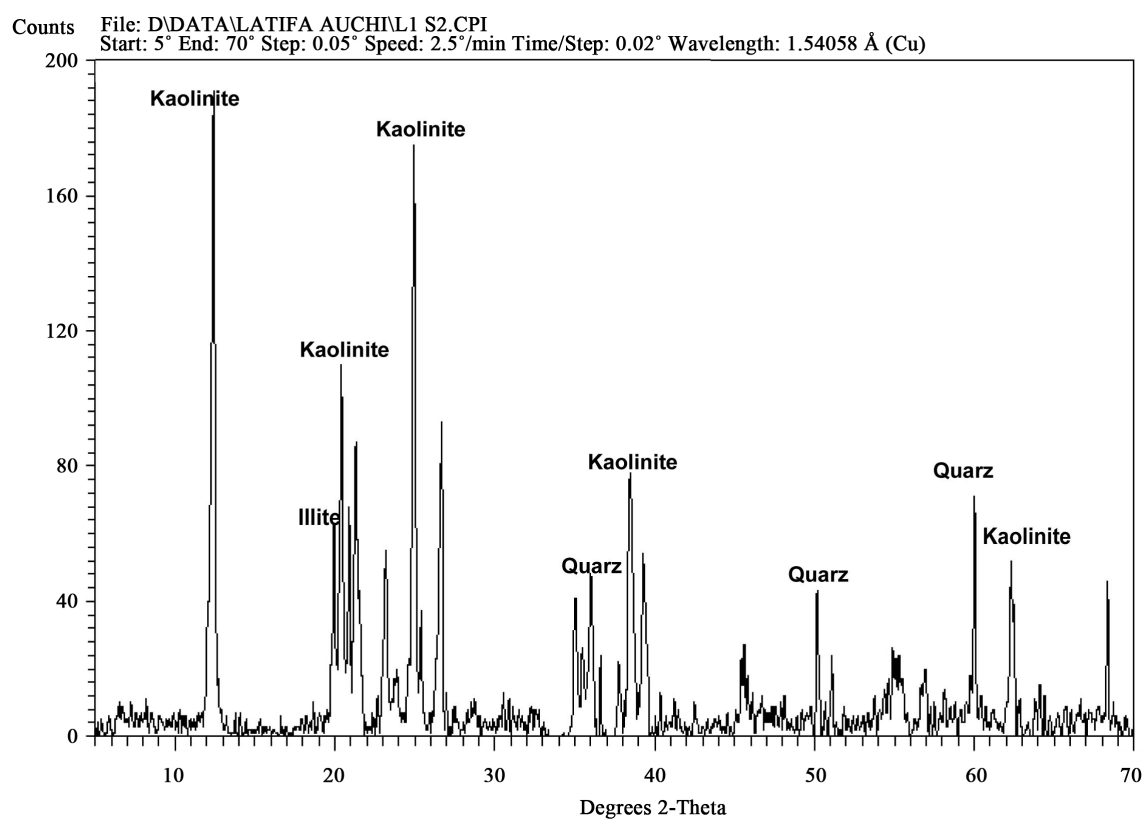

Figure 5. XRD diffractograph for sample L1S1 in Ajego 1.

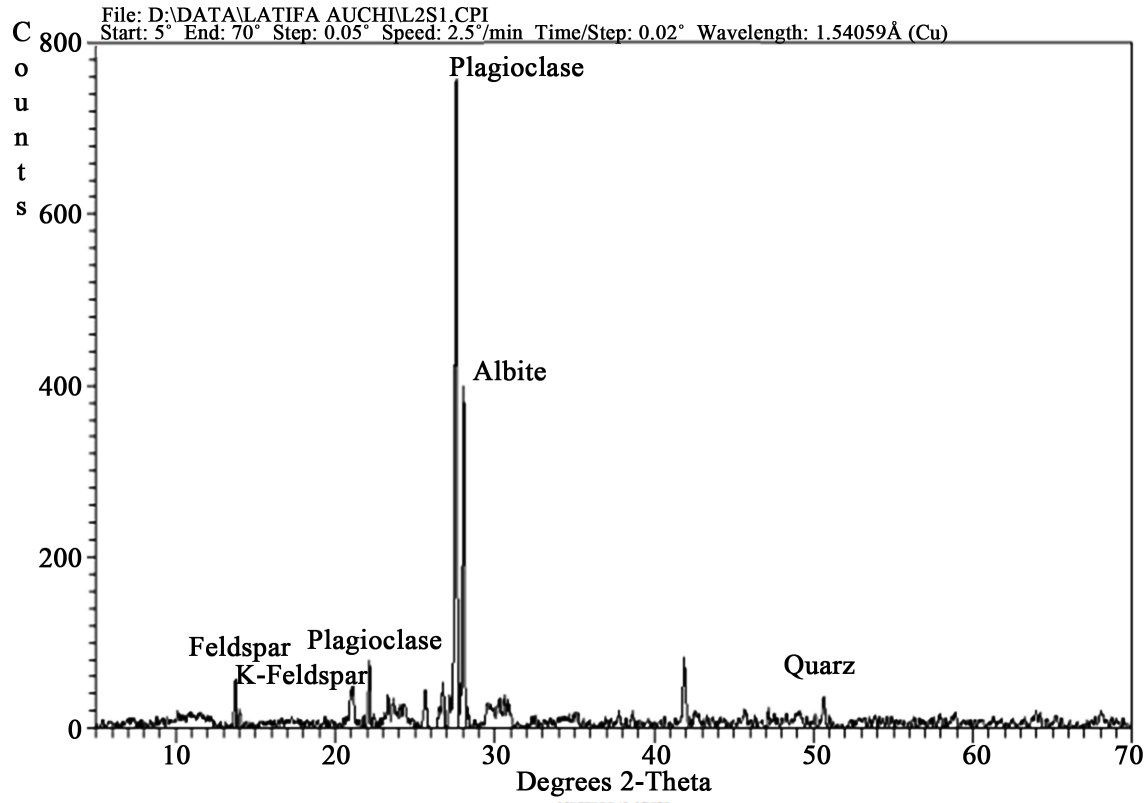

Figure 6. XRD diffractograph for Sample L2S2 in Ajego 2.

Kaolin and the clay mineral kaolinite are natural components of the soil and occur widely in ambient air as floating dust. Kaolinite is formed mainly by the decomposition of feldspars (potassium feldspars), granite, and aluminium silicates. The type of clay mineral formed during the decay of rocks containing $\mathrm{Al}$-silicates is influenced by the climate, the aluminium/silicon ratio, and $\mathrm{pH}$. Conditions conducive for kaolinite formation are strong dissolution of $\mathrm{Ca}^{2+}$, $\mathrm{Mg}^{2+}$, and $\mathrm{K}^{+}$and the presence of $\mathrm{H}^{+}$at $\mathrm{pH} 4-5$ [14]. Kaolinite quarries can be categorized according to the geo-historical age of the parent rock: 


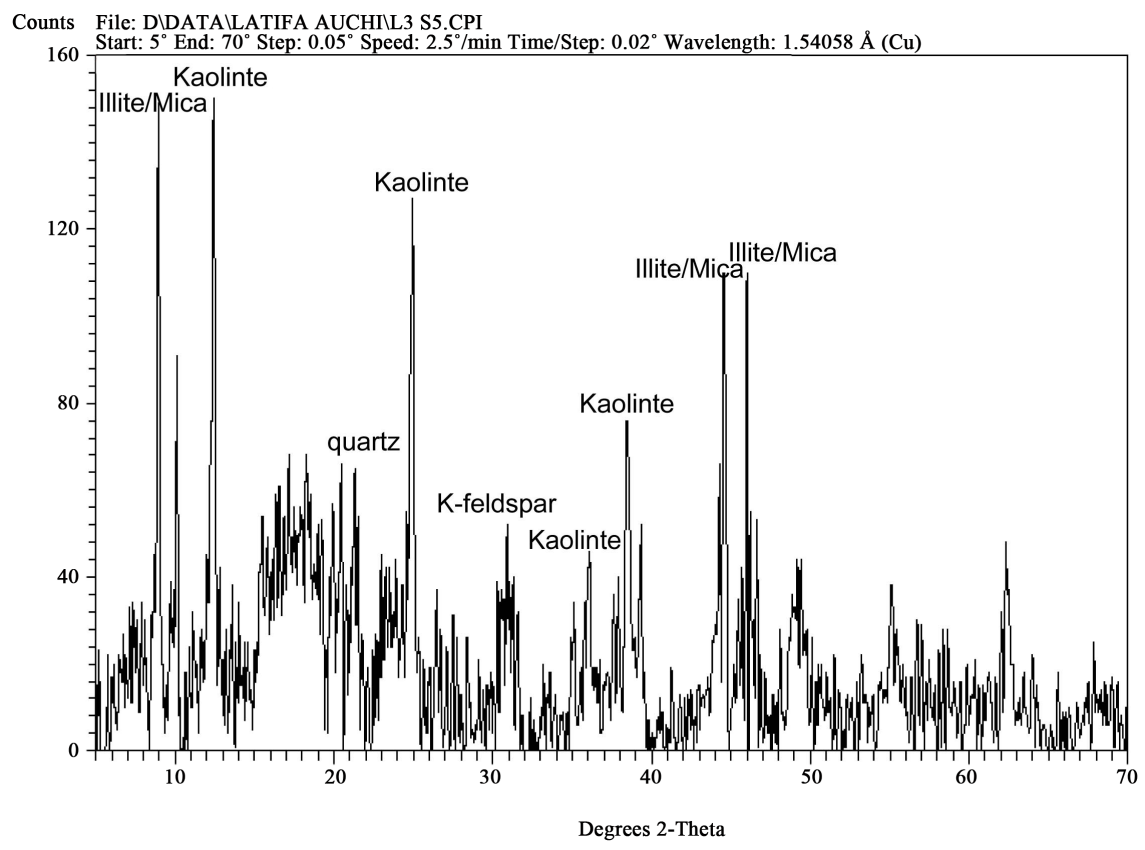

Figure 7. XRD diffractograph for samples L3S5 in Anegha.

1) Pre-Cambrian (Ukraine, Spain, Czech and Slovak republics),

2) Post-Cambrian (Cornwall, England, and Ural Mountains, Russia),

3) Palaeo-volcanite (Meissen, Germany) and,

4) Neo-volcanite (Tokaj Mountain, Hungary).

Kaolin clays can also be categorized as either primary $\left(1^{\circ}\right)$ or secondary $\left(2^{\circ}\right)$ according to whether it is in situ at the place of formation or transported [15] [16]. Those from primary origin are formed mainly under tropical climatic conditions, while kaolin of secondary origin is transported by different forces, water and wind.

As a result, several kinds of minerals may occur in natural kaolin clays. For example, the kaolin of Cornwall, England, contains 10\% - 40\% kaolinite; the rest is made of quartz, mica, and feldspar. The kaolin of Georgia, USA, contains $85 \%$ - 95\% kaolinite, as well as quartz, muscovite, and feldspar [17]. The Kaolin deposits of Okpella area (Ajego and Anegha) is of the Cornwall England type, because of its 10\% - 40\% kaolinite content (Figure 3 and Figure 5) and in terms of climatic factor the Zettlitz type is most likely attributable to the kaolinization process of the kaolin deposit in the study area. The presence of the thick lateritic cover further provides proofs to this claim (Figure 3(c) and Figure 3(d)). Contacts between the kaolin concentrations and the overlying laterite cover are sharp, suggesting transport rather than in-situ decomposition. A sedimentary deposit of commercial importance may be produced wherein conditions are favourable for an adequate amount of the clay to be separated from associated non-clay material, deposited without appreciable "dilution" by other detritus or chemical precipitates and preserved from subsequent alteration or erosion [18]. Generally, the Kaolin occurs as white to light grey, with variable iron oxide 
staining which results in red colouration in some places (Table 2).

The presence of iron in the clay samples is clearly observed although in various amounts; this has been supported by various studies as a rule rather than exception [19] [20] [21]. The Ajego 1 samples contain higher amount of kaolinite $(>50 \%)$ and illite compare to the other samples with a marked absence of feldspars in the deposit which must have been fully altered to the kaolinite. The sample clearly has an Illite clay mineral association.

The Ajego 2 will except with the addition of some additive that will improve on their refractory properties, cannot be used to produce good refractory materials for high temperature applications because of its high feldspar content which favors a liquid phase formation and densification at low temperature [22] [23] [24] [24] [26]. Moreover, feldspars are important raw materials for ceramic and glass industries and chemical compositions; their alkali contents determine their quality and price [25]. The feldspars in the whole study areas are of the alkali feldspar composition. Industrial application of feldspars is based on their ability to fuse at relatively low temperatures to generate glass. This property enables its usage in the ceramics and glass industries. Also, the alkali feldspar is necessary for the production of liquid phase during sintering which accelerates reactions and contributes to the formation of high-temperature crystalline compounds and densification of ceramics [26]. Also the Dansa quarries samples in Anegha has a mixture of alkali feldspar (Figure 5) and kaolinite with mixed layer of illite/mica minerals; this makes it unsuitable for the production of high temperature caliber refractories except with additives to improve its refractoriness. Illite as a major component in the Anegha sample is used mainly in the production of bricks, Portland and other cements, concrete, highway surfacing, ceramics tiles and glass [27]. Illite can also be used to coat welding rods because of its fluxing properties, it increases the plasticity and workability of the porcelain mass and produces superior end product by filling the gap in the kaolin crystals. [28] also suggested that illite could serve as a less expensive substitute for feldspar in ceramics, while the general chemical composition of the Okpella kaolin is suitable in pigment production according to the standards in [29].

\section{Conclusions}

1) This study has established the origin of the Okpella area kaolin to be of sedimentary-type formed by the decomposition of some igneous rocks and later transported and is deposited in its present position.

2) The Okpella kaolin can be used for many industrial applications which include but are not limited to the production of ceramic tiles, Portland cements and as pigments in paint production, and as fillers for papermaking.

3) Sufficient mineralogical and chemical characterization of the deposits revealed the presence of the oxides $\mathrm{SnO}_{2}, \mathrm{Fe}_{2} \mathrm{O}_{3}, \mathrm{ZnO}$ and $\mathrm{NiO}$. Even though they are in trace amounts, they will help the potential investor with an informed decision regarding beneficiation. 


\section{Acknowledgements}

We wish to thank Mr. Ofiwe Collins of the National Agency for Science and Engineering Infrastructure Akure, Ondo State Nigeria for running all the Laboratory tests.

\section{Conflicts of Interest}

The authors declare no conflicts of interest regarding the publication of this paper.

\section{References}

[1] Idenyi, N.E. and Nwajagu, C.O. (2003) Non-Metallic Material Technology. Olison Publication, Enugu.

[2] Murray, H.H. (1999) Applied Clay Mineralogy Today and Tomorrow. Clay Minerals, 34, 39-49. https://doi.org/10.1180/000985599546055

[3] Ekpunobi, U.E., Duru, C.B., Ogbuagu, A.S. and Obumselu, E.O. (2013) Analysis and Characterization of Clay Deposits in Idemili River, South Eastern Nigeria. Pelagia Research Library, Der Chemica Sinica, 4, 6-9.

[4] Baker, C.J. and Uren, R.E. (1982) Kaolin in New South Wales. Geological Survey of New South Wales, 231.

[5] Murray, H.H. (1988) Kaolin Minerals: Their Genesis and Occurrences. In: Bailey, S.W., Ed., Hydrous Phyllosilicates (Exclusive of Micas) Reviews in Mineralogy, Mineralogical Society of America, Washington DC, Vol. 19, 67-90.

[6] Cravero, E. and Dominguez, F. (1999) Origin of Sedimentary Kaolin in the Neuquen Basin, Argentina as Determined by Oxygen Isotopes. Periodico di Mineralogia, 68, 213-222.

[7] Hassan, M.D. (2014) Geochemistry and Origin of the Cretaceous Sedimentary Kaolin Deposits, Red Sea, Egypt. Geochemistry, 74, 195-203.

[8] Lima, P.A., Angélica, R. and Neves, R. (2017) Dissolution Kinetics of Amazonian Meta-Kaolin in Hydrochloric Acid. Clay Minerals, 52, 75-82.

https://doi.org/10.1180/claymin.2017.052.1.05

[9] Kotal, M. and Bhowmick, A.K. (2015) Polymer Nano-Composites from Modified Clays: Recent Advances and Challenges. Progress in Polymer Science, 51, 127-187. https://doi.org/10.1016/j.progpolymsci.2015.10.001

[10] Liu, P., Farzana, R., Rajarao, R. and Sahajwalla, V. (2017) Lightweight Expanded Aggregates from the Mixture of Waste Automotive Plastics and Clay. Construction and Building Materials, 145, 283-291.

https://doi.org/10.1016/j.conbuildmat.2017.04.009

[11] Imerys, P. (2013) Calcined Clays in Light Weight Coatings Technical Guides. http://www.imerys-paper.com/Technical/Guide/Calcined/Clayin_LWCpdf

[12] Clark, M.D.T. (2013) Paints and Pigments Review. http://www.nzic.org.nzChemProcess/polymer/10D.pdf

[13] Rahaman, M.A. (1988) Recent Advances in the Study of the Basement Complex of Nigeria. Symposium on the Geology of Nigeria, Obafemi Awolowo University.

[14] Parker, S.P. (1988) McGraw-Hill Encyclopedia of the Geological Sciences. 2nd Edition, McGraw-Hill, New York, 32-33, 69-72.

[15] Kuzart, M. (1984) Betonite and Monmorrllonite Clayin: Industrial Minerals and 
Rocks. Elsevier, Amsterdam, 280-287.

[16] Hosterman, J.W. and Patterson, S.H. (1992) Betonite and Fuller's Earth Resources of the United States. US Geological Survey, Washington DC, 45.

[17] Patterson, S.H. and Murray, H.H. (1975) Clays. In: Lefond, S.I., Ed., Industrial Minerals and Rocks, 4th Edition, American Institute of Mining, Metallurgical, and Petroleum Engineers, New York, 519-595.

[18] Bates, T.F. (1964) Geology and Mineralogy of the Sedmentary Kaolins of the Southeastern United States: A Review. In: Clays and Clay Minerals, Pergamon Press, New York, 177-194.

[19] Petit, S., Robert, J.L., Decarreau, A., Besson, G., Grauby, O. and Martin, F. (1995) Contribution of Spectroscopic Methods to 2/1 Clay Characterization. Bulletin des centres de Recherches Exploration-Production Elf Aquitaine, 19, 119-147.

[20] Grauby, O., Petit, S., Decarreau, A. and Baronnnet, A. (1994) Nontrionite-Saponite Series: An Experimental Approach. European Journal of Mineralogy, 4, 99-112. https://doi.org/10.1127/ejm/6/1/0099

[21] Giresse, P. and Wiewiora, A. (2001) Stratigraphic Condensed Dposition and Diagenetic Evolution of Green Clay Minerals in Deep Water Sediments on the Ivory Coast-Ghana Ridge. Marine Geology, 179, 51-70. https://doi.org/10.1016/S0025-3227(01)00193-1

[22] Ergul, S., Akyildiz, M. and Karamanov, A. (2007) Ceramic Material from Basaltic Tuffs. Industrial Ceramics, 27, 89-94.

[23] Aramide, F.O. (2012) Effect of Firing Temperature on Mechanical Properties of Fired Masonry Bricks Produced from Ipetumodu Clay. Leonardo Journal of sciences, 70-82.

[24] Aramide, F.O. (2012) Production and Characterization of Porous Insulating Fired Bricks from Ifon Clay with Varied Sawdust Admixture. Journal of Minerals and Materials Characterization and Engineering, 11, 970-975. https://doi.org/10.4236/jmmce.2012.1110097

[25] Bayraktar, I. and Çakır, U. (2002) Quality Feldspar Production at Çine Akınaden. Industrial Minerals, 56-59.

[26] Sedmale, G., Sperberga, I., Sedmalis, U. and Valancius, Z. (2006) Formation of High-Temperature Crystalline Phases in Ceramics from Illite Clay and Dolomite. Journal of the European Ceramic Society, 26, 3351-3355. https://doi.org/10.1016/j.jeurceramsoc.2005.10.012

[27] Virta, R.L. (2002) US Geological Survey Mineral Industry Surveys. Clay and Shale. http://minerals.usgs.gov/minerals/pubs/commodity/clays/claysmyb02.pdf

[28] Fan, C.M. and Aw, P.C. (1988) Processing of Illite Powder in Bidor, Perak: A Study of the Process and Potential Use of Illite Clay. Buletin Persatuan Geologi Malaysia, 15,37 .

[29] Mesbah, H., Wilson, M.A. and Carter, M.A. (2011) The Role of the Kaolinite-Mullite Reaction Sequence in Moisture Mass Gain on Fired Kaolinite. http://www.scientific.net/ATS.68.38.pdf 